\title{
VERSLAG VAN DE VIERDE ALGEMEENE VERGADERING VAN HET KONINKLIJK INSTITUUT VOOR DE TAAL- LAND- EN VOLKENKUNDE VAN NEÊRLANDSCH INDIË,
}

GEHOUDEN TE DELFT, DEN 22 STEN APRIL 1854 , DES vOORMIDDAGS TE 11 UUR.

De Vice-President neemt, bij afwezigheid van den President, het praesidium op zich en opent de Vergadering.

De Secretaris leest de Notulen der vorige Vergadering en geeft, namens het Bestuur, een Overzigt van den staat en de verkzaamheden des Instituuts gedurende het afgeloopen jaar 1853/54. (Bijlage A).

De President benoemt twee leden als commissie ter opname van de rekening en verantwoording van het Bestuur gedurende dat zelfde tijdvak.

De drie aftredende leden van het Bestuur, de HН. GUYот, SMISSAERT en WINTGENS, worden herkozen.

De President doet in naam van het Bestuur drie voorstellen, welke sén voor één door de Vergadering worden aangenomen:

ten eerste: dat de Vergadering magtiging verleene om voort te gaan met de nieuve leden zonder stemming toe te laten, tot dat het haar zal goeddunken deze magtiging weder in te trekken; 
vervolgens, om, onder gelijke bepaling, de algemeene Octobervergadering voortaan niet te doen plaats hebben;

eindelijk, om de Huishoudelijke bepalingen voor goed te arresteren.

Daarna wordt, daar niemand het woord verlangt, de Vergade-

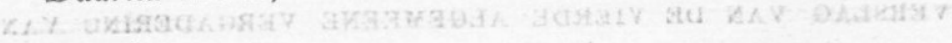
ring gesloten. 